University of Nebraska - Lincoln

DigitalCommons@University of Nebraska - Lincoln

Faculty Publications from the Harold W. Manter Laboratory of Parasitology

$11-1974$

\title{
Helminths of Three Species of Goby (Pisces: Gobiidae) from Mission Bay, San Diego
}

Daniel R. Brooks

University of Toronto,dnlbrooks@gmail.com

Edward B. Brothers

Scripps Institution of Oceanography

Follow this and additional works at: https://digitalcommons.unl.edu/parasitologyfacpubs

Part of the Parasitology Commons

Brooks, Daniel R. and Brothers, Edward B., "Helminths of Three Species of Goby (Pisces: Gobiidae) from Mission Bay, San Diego" (1974). Faculty Publications from the Harold W. Manter Laboratory of Parasitology. 226.

https://digitalcommons.unl.edu/parasitologyfacpubs/226

This Article is brought to you for free and open access by the Parasitology, Harold W. Manter Laboratory of at DigitalCommons@University of Nebraska - Lincoln. It has been accepted for inclusion in Faculty Publications from the Harold W. Manter Laboratory of Parasitology by an authorized administrator of DigitalCommons@University of Nebraska - Lincoln. 


\section{Helminths of Three Species of Goby (Pisces: Gobiidae) from Mission Bay, San Diego}

From August 1971 to June 1973, 351 gobies representing three species, Ilypnus gilberti (Eigenmann and Eigenmann), Clevelandia ios (Jordan and Gilbert), and Quietula y-cauda (Jenkins and Evermann), were collected by the junior author from Mission Bay, San Diego, California, and examined for helminths. The worms were removed from the organs to saline solution, fixed in $40 \%$ isopropyl alcohol or warm AFA, and stored in $70 \%$ ethanol. All platyhelminths were stained in Mayer's hematoxylin and mounted in Canada balsam. Nematodes were cleared in glycerine and mounted in glycerine gel. Representative mounts are on deposit with the H. W. Manter Laboratory, Division of Parasitology, University of Nebraska State Museum. Specimens of one digenetic trematode, two larval cestodes, and one nema- 
tode were recovered. This is the first report of any of these fish species as hosts for helminth parasites.

The trematode, Lecithaster minimus Martin and Multani, 1970, has previously been reported only in Gillichthys mirabilis Cooper from Scammon Lagoon, Baja California, Mexico [39 (34\%) of 116 fish infected, a mean of 1.3 worms per infected host]. The present collection represents a range extension for this worm. Twenty-six (22\%) of 118 Clevelandia ios harbored a mean of 3.4 worms per infected host, $18(17 \%)$ of 96 Quietula y-cauda harbored a mean of 7.2 worms per host, and 39 (37\%) of 137 Ilypnus gilberti harbored a mean of 10.9 worms per host.

All three host species were infected with a larval trypanorhynch cestode belonging to the genus Callitetrarhynchus Pintner, 1931. Infection rates were $20 \%$ - a mean of 9.0 worms per host for Clevelandia ios, 29\%-a mean of 8.6 worms per host for Quietula y-cauda, and 27\% - a mean of 4.9 worms per host for Ilypnus gilberti.

A larval tetraphyllidean cestode was found in $62 \%$ of the Quietula y-cauda and 15\% of the Ilypnus gilberti, primarily in the gall bladder, occasionally in the gut, or in the mesenteries around the esophagus, surrounded by fibrocytic cells. Dr. Juan Carvajal (pers. comm.) indicated his belief that it is Scolex pleuronectis Mueller, 1788, reported from various fish in the Atlantic Ocean by many authors (notably Euzet, 1959, Thèse (Montpellier), 263 p.; and
Williams, 1969, Nytt Mag. Zool. 17: 1-56). They are thought to be larval forms of members of the family Onchobothriidae, possibly of the genus Acanthobothrium Van Beneden, 1849, in which the bothridial hooks have not yet developed. Our specimens, the first members of this form reported from the Pacific Ocean, are similar to the larvae reported by Hamilton and Byram (1974, J. Parasit. 60: 20-28), a fact which supports this conclusion.

An adult nematode was recovered from all three host species. A member of the genus Spirocamallanus Olsen, 1952, the worm resembles S. pereirai (Annereaux, 1946) Olsen, 1952, but may belong to an undescribed species. We feel that further work must be done before the taxonomic status of this species is ascertained. Clevelandia ios ( $10 \%$ infectedmean of 4.7 worms per host) was again more lightly infected than Quietula y-cauda (51\%-a mean of 3.7 worms per host) and Ilypnus gilberti ( $74 \%$ - a mean of 5.5 worms per host).

The authors wish to thank Dr. Juan Carvajal G., Instituto de Ciencias Biologicas, Universidad Católica de Chile; Dr. Elmer Noble, University of California, Santa Barbara; and Mrs. Mary Hanson Pritchard, Harold W. Manter Laboratory of Parasitology, for their assistance in this endeavor.

Daniel R. Brooks, H. W. Manter Laboratory, Division of Parasitology, University of NebraskaLincoln, Lincoln, Nebraska 68508, and Edward B. Brothers, Graduate Department, Scripps Institution of Oceanography, La Jolla, California 92037 